\title{
The Relationship between Capital Structure and Performance of Non-Financial Firms Listed on the Amman Stock Exchange
}

\author{
Faraj Salman Alfawareh ${ }^{1 *} \quad$ Ahmad Almashaqbeh ${ }^{2} \quad$ Mahmoud Al-Kofahi $^{3} \quad$ Malek Alshirah $^{4}$ \\ Husam Ananzeh $^{3} \quad$ Bara'a Al-Kofahi $^{5}$ \\ 1 School of Economics, Finance and Banking, Universiti Utara Malaysia \\ 2 School of Accountancy Universiti Utara Malaysia \\ 3 Faculty of Administrative and Financial Sciences, Irbid National University, Jordan \\ 4 Accounting Department, Al al-Bayt University, Jordan \\ 5 Deanship of Educational Services-Computer science unit, Qassim University, Saudi Arabia
}

\begin{abstract}
The aim of this study is to take a step forward to examine the relationship between capital structure and firm performance particularly concentrating on the firms listed on Amman Stock Exchange (ASE). The current study uses 95 sample firms from non-financial firms listed on ASE. The period of the present study is (2013 - 2017). The regressions have been shown and the results are showed rely upon the fixed effect model. The results show that all variables represent capital structure by Total Debt to Total Assets, Long Term Debt to Total Assets, Firm Size, Sales growth, Tangibility, and Liquidity have the relationship to firm's performance represents by return on assets and Tobin's Q. Sales growth and Total Debt to Total Assets have statistically positive significant relationship with firm's performance. Meanwhile, Long Term Debt to Total Assets and Liquidity show a statistically insignificant relationship with firm performance. Similarly, Tangibility has a statistically negative significant relationship with Tobin's Q and return on assets. Lastly, the study is contributed to top managers by providing value of an effective and efficient capital structure to firm performance in Jordanian business environment, by facilitating them in improving their capital structures to maximise shareholders' wealth as well as findings of this study will be important to other researchers by providing empirical evidence on the influence of capital structure on firm performance.
\end{abstract}

Keywords: Amman Stock Exchange, Capital Structure, Firm's Performance, Jordan

DOI: $10.7176 /$ RJFA/13-2-09

Publication date: January $31^{\text {st }} 2022$

\section{Introduction}

The surge of interest amongst shareholders in the dynamic nature of businesses, as well as the growth and evaluation of firm performance (FP), is on the increase. Therefore, monitoring FP using different measurements is vital for business survival and competitiveness (Önel \& Gansuwan, 2012; Naseem et al., 2020; Alfawareh et al., 2021). According to Margartis and Psillaki (2010), Numerous studies in the field of financial management have focused on key determinants of FP towards development. Depending on the focus, FP could be linked to the firm's strategies, its capacity to identify and grasp business openings and advancements and the ability to compete and venture into new markets.

However, decisions on investment and finance are important strategies for determining the best alternatives for enhancing FP. Business failure can be averted by employing such strategies that involve financing decisions, which can push a firm to higher growth and improved performance. For this reason, appropriate financing decisions are vitally important for the company to expand its activities and generate higher revenues, which can be translated into higher FP (Ahmed Sheikh \& Wang, 2012; Ananzeh et al., 2021; Ayaz et al., 2021). Capital structure (CS) is a product of financing decisions, which requires proper optimisation to avert corporate failure. The existence of an optimal CS has continued to pose a challenge to both management and business investors alike.

Therefore, the firm must make certain that it chooses the optimal CS because employing an inappropriate CS will result in a high cost of capital as a result lead to the low value of the company. In contrast, selecting an optimal CS can push the firm value up and assist firms to manage the competitive environment by augmenting its operational activities (Ahmed et al., 2019; Alfawareh, 2019; Ananzeh, 2020). Every personnel responsible for making financial decisions is charged with the objective of maximising wealth and the value of such decisions can be assessed by measuring the effect of the decision on FP.

Of late, many studies have scrutinised the CS in firms in developing countries and the results affirm its effects. Jordan, as an emerging market, is facing several internal financial issues and business challenges because of regional instability (Alabdullah, 2016) However, Almajali and Shamsuddin (2019) indicated that there is a lack of empirical studies on the relationship between CS and FP in Jordan. There are some studies available on CS and debt ratio. Further, some of the previous studies, like Ramadan and Ramadan (2015), have investigated CS in the industrial sector. Tayem (2018) examined CS and performance in the banking sector. Although Soumadi and Hayajneh (2012) studied the CS and its effect on FP in Jordan, still, there are very few empirical studies undertaken 
on both the service and industrial sectors regarding firm growth. Besides, analysing the CS in the non-financial sector has also been neglected. Further, previous results are inconclusive since findings have been mixed. Some studies (Dawar, 2014; Ramadan \& Ramadan, 2015; Matar \& Eneiza, 2018) have found a significant and positive association between FP and CS; while others (Hasan et al., 2014; Rouf, 2015; Li et al., 2019) have documented a negative and significant association between FP and CS. In addition, in other studies, an insignificant association has been found between CS and FP (Ebaid, 2009).

So, the key main concern of our study is to examine the relationship between CS and FP in the Jordanian environment. Numerous researches have examined the relationship between CS and FP in developed countries like (Berger \& Patti, 2006; Margaritis \& Psillaki, 2007; Li et al, 2019; Spitsin et al., 2020), nevertheless, this study is directed to an emerging market, i.e., the Jordanian market whereby a few studies investigated the relationship between CS and FP (e.g. Shamsuddin et al., 2018; Tayem, 2018). Therefore, the present study, contribute by fill this gap which needs more studies to clarify and analyse the CS and FP of the Jordanian non-financial sector, consisting of the industrial and services firms. Furthermore, the study is contribute to managers by presenting the value of an effective and efficient CS to FP, by facilitating them in improving their CS to maximise shareholders' wealth.

\section{Theoretical Background and Previous Literature}

Defenders of optimal capital structure claimed that judicious combination of debt and equity increase the firm's value. Thus, the CS theory was proposed by the Modigliani and Miller (1958). The assumptions in the theory are no transaction cost, perfect capital markets, no bankruptcy cost and no taxation. Therefore, the market value of a company is claimed to be separate of its CS. Information symmetry and other changes made in a company's CS have no long-term effects on a company's market value. Modigliani and Miller (1958) proposed that under perfect economic conditions, financing does not influence since the company's value is not dependent on how debt plus equity are structured. As well, the trade-off theory between bankruptcy cost and the marginal present value of tax determines the best debt ratio of companies. This is why tax benefits, in terms of marginal present value, increase firm value and thereby decrease distress cost (Bradley et al., 1984; Alfawareh, 2019). Additionally, Jensen and Meckling (1976) were the first to suggest the Agency Cost Theory. This theory assumes that conflicts of interest exist in the organisation or corporation which are not aligned with the effort to maximise the shareholders' wealth (Margaritis \& Psillak, 2007). The previous literature on the association between CS and FP has found mixed results. However, Sadeghian et al. (2012) examined the association between long term debt (LTD) and FP in Tehran Stock Exchange, using a combination of accounting measurements return on assets (ROA), return on equity (ROE), and Tobin's Q, they are found the association to be negative. Saeedi and Mahmoodi (2011) investigated the effect of total debt and long term debt on ROA and Tobin's Q. The result indicates that CS has a positive significant association with Tobin's Q and a negative relationship with ROA. Berger and Patti (2006) explained the FP of the CS of 588 listed commercial banks in the USA for the 1990-1995 period. The findings indicate a strong correlation and it is economically significant. Hoang and Linh (2021) analysed the influence of debt ratios on the listed firms' performance over a period of eight years. It was found that Total Debt to Total Assets (TDTA) correlate positively to profitability measured by ROE. Nawaz et al. (2011) and Spitsin et al. (2020) found that the TDTA ratio has a significant and positive influence on Tobin's Q, ROE, and ROA. The results confirm that high percentage of debt in CS favorably impact on firm's performance. Nguyen and Hosseini (2019) employed Tobin's Q \& ROA to measure firm size and found firm size has a significant and negative association with Tobin's Q and ROA. Ahmed and Afza (2019) employed the use of competitive intensity as a moderator in the relationship between CS and FP, measured by Tobin's Q, ROE, and ROA of Pakistani non-financial firms. They found that size is significantly positively associated with ROE, ROA and Tobin's Q. Dada and Ghazali (2016) employed similar measures of CS to investigate the performance of non-financial firms on the Nigerian Stock Exchange. Using ROA \&Tobin's Q as a measure for FP, they found that sales growth (GROWTH) has a positive significant association with ROA and Tobin's Q. Tailab (2014) argued there is a positive association between growth rate and FP (Tobin's Q and ROA). Nguyen et al. (2020) empirically proved that tangibility (Tang) and FP have a negative association, which is quite similar to ROA and Tobin's Q. Muzir (2011) found out that ROA and tangibility have a positive association. In their study, Almajali and Shamsuddin (2019) reported that liquidity (LIQ) has a positive effect on financial performance. Nguyen et al. (2020) and Sadeghian et al. (2012) found out a negative significant association between liquidity and FP, proxies by ROA and Tobin's Q.

\section{The Methodology of The Study}

This study used only two sectors, i.e., the industry and service sectors, which constituted a total of 118 nonfinancial listed firms on ASE. However, the current study finally used only 95 firms out of the 118 firms due to missing data of some firms, and hence, these firms were dropped from the current study. This led to 475 observations for the entire final sample ( 95 firms multiplied by five years). Panel regression analysis and Hausman Test were used in the present work. The tests are used to discover the best model that can explain the influence of 
the CS on the FP. The fixed effect (FE) regression is incorporated when the specific component is not an Independent variable. In contrast, the random effect (RE) is incorporated when the specific component is a dependent variable. When the Hausman test shows that $\mathrm{p}$-value is $<5 \%$, it provides the justification to use $\mathrm{FE}$ regression. But when results are $>5 \%$, the RE regression is used.

The regression models.

ROA $_{i t}=\alpha+\beta 1$ LTDTA $_{i t}+\beta 2$ TDTA $_{i t}+\beta 3$ SIZE $_{i t}+\beta 4$ GROWTH $_{i t}+\beta 5$ Tang $_{i t}+\beta 6 \mathrm{LiQ}_{\text {it }}+\mathrm{u}$ it (1)

Tobin $Q_{\text {it }}=\alpha+\beta 1$ LTDTA $_{i t}+\beta 2$ TDTA $_{i t}+\beta 3$ SIZE $_{\text {it }}+\beta 4$ GROWTH $_{\text {it }}+\beta 5$ Tang $_{\text {it }}+\beta 6 \mathrm{LiQ}_{\text {it }}+\mathrm{u}$ it (2)

\subsection{Definitions of variables}

Table 1. Definitions of variables

\begin{tabular}{|l|l|l|}
\hline Variable category & Symbol & Proxy \\
\hline Dependent variables & & \\
\hline Return on Asset & ROA & Net income divided overall assets (Hoang \& Linh, 2021). \\
\hline Tobin Q & $\begin{array}{l}\text { Tobin's } \\
\text { Q }\end{array}$ & $\begin{array}{l}\text { The total market value of the company divided the overall total } \\
\text { assets value of the company (Vo \& Nguyen, 2014). }\end{array}$ \\
\hline Independent variables & & \\
\hline Long-Term Debt to Total Assets & LTDTA & Long term divided overall total assets (Ahmed \& Afza, 2019). \\
\hline Total Debt to Total Assets & TDTA & Total debt divided overall total assets (Spitsin et al., 2020) \\
\hline Firm size & SIZE & Natural logarithm of overall total assets (Ahmed \& Afza, 2019). \\
\hline Liquidity & LiQ & $\begin{array}{l}\text { The proportion of current assets to current liabilities (Almajali \& } \\
\text { Shamsuddin, 2019). }\end{array}$ \\
\hline Tangibility & TANG & Fixed assets divided overall total assets (Muzir, 2011). \\
\hline Sales growth & GOWTH & $\begin{array}{l}\text { The sales of the present year and subtracting sales of the last or } \\
\text { last year, divided by sales of last (Conyon \& He, 2012). }\end{array}$ \\
\hline
\end{tabular}

Source: Prior studies

\section{Results}

\subsection{Descriptive Analysis}

Base on Table 2, the descriptive statistics results show that the mean value of ROA is .012, it shows efficiency is not high, and Jordanian firms need to improve ROA to attract investors. In the same manner, accourding to Table 2 the mean of Tobin's Q is .011. So, the ROA of performance indicates that firms in Jordan have a low performance. Similarly, for Tobin's Q the greatest proxy of performance in Jordanian firms, the high ratios of Tobin's $Q$ can be as a result of the rise in equity and companies' stock price without a corresponding rise in the actual firm's performance.

Evidence in Table 2 displays the mean of LTDTA is .181. The ratio of TDTA has a mean of .292. This indicates that .292 of the assets of the company is financed through debt. So, regarding Jordanian firms, a mean value of firm growth is -1.815 . This implies that the level of growth among listed Jordanian companies is uneven. Firm size mean is 10.022. Similarly, the mean of TANG is 36.5 .Additionally, the mean value of LIQ is 1.615. Hence, Jordanian firms maintain a good level of its liquidity (161\%) to be safe and be able to meet their obligations. Table 2. Descriptive Analysis

\begin{tabular}{|l|l|l|l|r|}
\hline Variables & Mean & Std. Dev & Min. & Max. \\
\hline ROA & .012 & .086 & -.614 & .387 \\
\hline Tobin's Q & .011 & .200 & -.856 & 1.129 \\
\hline LTDTA & .181 & .127 & .023 & .403 \\
\hline TDTA & .292 & .229 & .001 & 1.045 \\
\hline Size & 10.022 & 1.351 & 6.588 & 13.878 \\
\hline Growth & -1.815 & .292 & -27.7 & 22.883 \\
\hline TANG & .365 & 0 & .694 & .982 \\
\hline LIQ & 1.615 & .835 & 2.938 \\
\hline $\begin{array}{l}\text { Note: } \text { ROA=Return } \\
\text { to Total Assets, Size = Size of the firms, GROWTH= Sales Growth, TANG=Tangibility, LIQ=Liquidity }\end{array}$ \\
\hline
\end{tabular}

\subsection{Correlation Matrices}

Table 3 illustrates the Pearson correlations for this study and the variance inflation factors (VIF). The value of correlation is a measure of strength along with the direction of the correlation among 2 variables. For this study, Table 3 reports the correlation between CS and FP measures (Tobin's Q and ROA) of the six CS (TDTA, LTDTA, Size, Growth, TAN and LIQ). The purpose of applying the correlation coefficient is to assess the degree of linear association that exists amongst two variables or more. In Table 3, it can be showed that there is a negatively 
significant correlation between TDTA and Tobin's Q and ROA. This means that a greater level of TDTA leads to reduced performance. Besides, LTDTA is negatively correlated to ROA and positively correlated to Tobin's Q. Moreover, size is positively and significantly correlated with ROA and Tobin's Q, suggesting that large Jordanian firms are highly diverse and have easy access to capital with favourable interest rates. Also, growth is positively correlated with FP, while TANG has a negative association with Tobin's Q and ROA. Lastly, LIQ is positively correlated to the performance by ROA and Tobin's Q. Furthermore, no problem with multicollinearity has confirmed in the present study. As shown in Table 3, the value of mean VIF is less then 10 per cen.

Table 3. Correlation Matrices

\begin{tabular}{|c|c|c|c|c|c|c|c|c|c|}
\hline Variables & ROA & Tobin Q & TDTA & LTDAT & Size & Growth & TANG & LIQ & VIF \\
\hline ROA & 1 & & & & & & & & \\
\hline Tobin Q & & 1 & & & & & & & \\
\hline TDTA & -0.151 & -0.092 & 1 & & & & & & 1.280 \\
\hline $\begin{array}{l}\text { LTDTA } \\
\end{array}$ & -0.051 & 0.052 & 0.168 & 1 & & & & & 1.044 \\
\hline Size & 0.189 & 0.209 & 0.442 & 0.069 & 1 & & & & 1.262 \\
\hline Growth & 0.170 & 0.168 & 0.045 & -0.001 & 0.087 & 1 & & & 1.008 \\
\hline TANG & -0.154 & -0.104 & 0.079 & 0.099 & 0.067 & -0.012 & 1 & & 1.016 \\
\hline LIQ & 0.131 & 0.111 & 0.014 & -0.077 & -0.074 & -0.011 & 0.005 & 1 & 1.015 \\
\hline
\end{tabular}

\subsection{Fixed-Effects Regression Results - Model 1 ROA}

Table 4 reports the FE regression. The results show that R-squared is $16.9 \%$. This indicates that about $16.9 \%$ in ROA is illustrated by TDTA, LTDTA, GROWTH, SIZE, TANG and LIQ. Rahaman \& Alam (2014) investigated the CS of Jordanian companies, showed that there is a significantly negative relationship between TDTA and ROA. A negative relationship shows that agency problems could lead companies to use debt in its CS more than is appropriate, which limits the managers' capacity to manage the activities efficiently, thus negatively influencing FP. The result of this analysis is related with the pecking order theory, which states that debt is negatively linked with the firm's performance because high level of debt decreases the performance of the firms (Wassie, 2020). Furthermore, LTDTA has an insignificant but positive association with ROA. This might be due to the long-term debts to reduce the pressure for repayment. Size has a significant and positive relationship with ROA and link with the forecasts of the trade-off theory that larger companies tend to employ debt to have tax savings on interest costs. This result is line with Dada and Ghazali (2016). The outcome also illustrates that growth is significantly and positively linked to ROA, which means increased growth is reflected by an increase in FP in line with Ahmed and Afza (2019) and Afza and Ahmed (2017). This result confirms the view of the suggestion of the pecking order theory which clearly states that companies with growth opportunities be able to access debt to finance their investment opportunities so yielding a high growth level. Likewise, tangibility is negatively but significantly related to ROA. This result is consistent with Ayaz et al. (2021). The outcome also illustrates that Jordanian firms with higher liquid assets were found to have a higher ability to discover long-term investment chances. Liquidity has a negatively and insignificantly association with ROA is inconsistent with Ahmed and Afza (2019). So, the results of the study propose that Jordanian firms need to pay attention to the internal and external economic variables of firms in order to maintain acceptable levels of liquidity.

Table 4. Model 1

\begin{tabular}{|c|c|c|c|c|c|}
\hline ROA & Coef. & St. Err. & t-value & p-value & Sig. \\
\hline TDTA & -.244 & .039 & -6.29 & 0.000 & $* * *$ \\
\hline LTDTA & .006 & .015 & 0.36 & 0.715 & \\
\hline Size & .094 & .014 & 6.49 & 0.000 & $* * *$ \\
\hline Growth & .00 & 0.00 & 2.30 & 0.022 & $* *$ \\
\hline TANG & -.098 & .034 & -2.88 & 0.004 & $* * *$ \\
\hline LIQ & -.003 & .007 & -0.37 & 0.710 & \\
\hline Constant & -.816 & .141 & -5.78 & 0.000 & $* * *$ \\
\hline R-squared & 16.9 & & & & \\
\hline Prob $>$ F & 0.000 & & & & \\
\hline Hausman Test & 0.0048 & & & & \\
\hline No of obs & 475 & & & & \\
\hline
\end{tabular}




\subsection{Fixed-Effects of Model 2 - Tobin's $Q$}

Table 5, shows the finds of the FE model. Tobin's Q has a R-squared of 11.7\%, consistent with Afza and Ahmed (2017). TDTA has a significantly negative association with Tobin's Q. This finding is in consistent with Dada and Ghazali (2016) claimed that TDTA influences firm's performance or is related to increased performance (Tobin's Q). This finding is in line with Tristan and Huy-Cuong (2015) who claimed that TDTA influences firm's performance or is directly related to increased performance (Tobin's Q). LTDTA has an insignificant association with Tobin's Q is inconsistent with Hasan et al. (2014). In fact, this result shows that financing with LTDTA is not affected the profitability of companies in Jordan. Thus, this study proposed that by decreasing debt measure in firm's capital mix would rise the profitability of the shareholders' wealth and firm. Size has a significant influence on FP (Tobin's Q). Thus, large Jordanian firms are highly diverse and have easy access to capital with favourable interest rates and can benefit optimally from economies of scale. The find is in line with (Dawar, 2014; Ayaz et al., 2021). In addition, firm's growth has a significantly positive association with Tobin's Q, implying that as sales growth increases, then performance improves in jordanina firms. The results are in line with Ahmed and Afza (2019). Nguyen and Hosseini (2019) also found a negative and significant relationship between TANG and Tobin's Q. Jordanian firms invest more in fixed assets in a method that does not increase their performance. Similarly, Tobin's Q presents an insignificant but negative association with LIQ. Therefore, LIQ is unable to describe the variability of FP in Jordan for the period of this study is in line by (Bokpin et al, 2011).

Table 5. Model 2

\begin{tabular}{|c|c|c|c|c|c|}
\hline Tobin's Q & Coef. & St. Err. & t-value & p-value & Sig. \\
\hline TDTA & -.236 & .059 & -4.00 & 0.000 & $* * *$ \\
\hline $\begin{array}{l}\text { LTDTA } \\
\end{array}$ & .002 & .024 & 0.09 & 0.927 & \\
\hline Size & .109 & .022 & 4.98 & 0.000 & **** \\
\hline Growth & .001 & 0.00 & 2.43 & 0.016 & ** \\
\hline TANG & -.133 & .052 & -2.57 & 0.011 & ** \\
\hline LIQ & -.002 & .011 & -0.17 & 0.862 & \\
\hline Constant & -.939 & .215 & -4.37 & 0.000 & *** \\
\hline R-Squared & 11.7 & & & & \\
\hline Prob > F & 0.0000 & & & & \\
\hline Hausman Test & 0.000 & & & & \\
\hline No of obs & 475 & & & & \\
\hline
\end{tabular}

\section{Conclusions}

This study explains the relationship between CS and FP of Jordanian companies listed on the ASE, whereby CS is measured by the ratio of TDTA and LTDTA with Tobin's Q and ROA as indicators of FP. In addition, as a result of the big difference in operations and the employ of debt among non-financial firms, the study divided the sample of the study into two sectors, i.e., industrial and services sectors, and runs empirical regressions for nonfinancial firms by using FE model based on the Hausman test as a method of regression analysis because this method is considered as the best and the most efficient among the other methods of regression. Generally, extra profitable and liquid companies would tend to use a lesser amount of debt in their CS, but larger size, growth and tangible assets, tend to create risks for debt with long-term maturities. Jordanian companies are generally not more liquid and profitable or able to manage its debts in the long run besides control on burdens of repayment. Additionally, the study is also significant to top managers by providing value of an effective and efficient CS to FP in Jordanian business environment, by facilitating them in improving their CS to maximise shareholders' wealth. Future investors can also benefit from the study to plan better strategies for investing in a viable market. The provision of information on the CS and regulatory policies to financial institutions in Jordan and other developing countries is one of the major contributions of the study. Moreover. The current study recommends that CS is a vital factor affecting Jordan's FP and should the Jordanian firm to employ debts at an acceptable level to be able payments its obligations and carry up its operation to avoid bankruptcy besides should recover their capacity in profitability by reducing financial risk. Additionally, Jordanian firms should run a feasibility study before entering in new projects to be able to gerents profits and avoid losses to increase its value. However, the main limitation in this study is the inability to generalise the findings on a larger scale as well as the study only focuses on two sectors in Jordan as an emerging market which does not reflect the overall markets of developing economies. In Jordan, there are other sectors like financial sector, and hence, the outcomes of the current research are only limited to the sampled sector since not all the sectors are covered. Secondly, the data for the current study only covers a period 
of five years. Future researchers should employ the moderating role of competitive intensity measure using the Herfindahl-Hirschman Index with debt ratios. Likewise, they can also involve control variables, for instance, the age of firm and turnover rate in their model.

\section{References}

Afza, T., \& Ahmed, N. (2017). Capital Structure, Business Strategy and Firm's Performance: Evidence from Pakistan. European Online Journal of Natural and Social Sciences, 6(2), 302-319.

Ahmed Sheikh, N., \& Wang, Z. (2012). Effects of corporate governance on capital structure: empirical evidence from Pakistan. Corporate Governance: The International Journal of Business in Society, 12(5), 629-641.

Ahmed, N., \& Afza, T. (2019). Capital structure, competitive intensity and firm performance: evidence from Pakistan. Journal of Advances in Management Research ,16(5),796-813.

Alabdullah, T. T. Y. (2016). Are board size and ownership structure beneficial in emerging markets' firms? Evidence from Jordan. International Journal of Management \& Information Systems (IJMIS), 20(3), 87-94.

Alfawareh, F. S., Al-Kofahi, M., Daoud, L., Marei, A., \& Alkhazaleh, A. (2021). The Determinants of Capital Structure: A Conceptual Understanding of Non-Financial Firms in Jordan. Turkish Online Journal of Qualitative Inquiry (TOJQI), 12(8), 2144-2152.

Alfawareh, F. S. H. (2019). The relationship between capital structure and performance of non-financial firms listed in Amman Stock Exchange (Master dissertation, Universiti Utara Malaysia, Kedah, Malaysia). Retrieved from,https://etd.uum.edu.my/id/eprint/8205

Almajali, M., \& Shamsuddin, Z. (2019). The effect of capital structure on performance of insurance companies: evidence from Jordan. International Journal of Accounting, 4(20), 64-73.

Ananzeh, H. (2020). The Impact of Corporate Characteristics on Corporate Social and Environmental Disclosure in Jordan (Doctoral dissertation, Western Sydney University, Sydney, Australia). Retrieved from https://researchdirect.westernsydney.edu.au.

Ananzeh, H., Alshurafat, H. \& Hussainey, K. (2021). Do firm characteristics and ownership structure affect corporate philanthropic contributions in Jordan?, Journal of Financial Reporting and Accounting,https://doi.org/10.1108/JFRA-08-2020-0249

Ayaz, M., Mohamed Zabri, S. \& Ahmad, K. (2021). An empirical investigation on the impact of capital structure on firm performance: evidence from Malaysia. Managerial Finance, 47(8), 1107-1127.

Berger, A. N., \& Di Patti, E. B. (2006). Capital structure and firm performance: A new approach to testing agency theory and an application to the banking industry. Journal of Banking \& Finance, 30(4), 1065-1102.

Bokpin, G. A., Isshaq, Z. \& Aboagye - Otchere, F. (2011). Ownership structure, corporate governance and corporate liquidity policy. Journal of Financial Economic Policy, 3(3), 262-279.

Bradley, M., Jarrell, G. A., \& Kim, E. H. (1984). On the existence of an optimal capital structure: Theory and evidence. The Journal of Finance, 39(3), 857-878.

Conyon, M. J., \& He, L. (2012). CEO Compensation and Corporate Governance in China. Corporate Governance: An International Review, 20(6), 575-592

Dada, A. O., \& Ghazali, Z. B. (2016). The Impact of Capital Structure on Firm Performance: Empirical Evidence from Nigeria. Journal of Economics and Finance, 7(4), 23-30.

Dawar, V. (2014). Agency theory, capital structure and firm performance: some Indian evidence. Managerial Finance, 40(12), 1190-1206.

Hasan, M. B., Ahsan, A. M., Rahaman, M. A., \& Alam, M. N. (2014). Influence of capital structure on firm performance: Evidence from Bangladesh. International Journal of Business and Management, 9(5), $184-194$.

Hoang, L. D., \& Linh, D. P. M. (2021). Determinants of Profitability: Case Study of Real Estate Companies in Hochiminh Stock Exchange. Journal of Social and Political Sciences, 4(3),1-13.

Jensen M. C. \& Meckling W. H. (1976). Theory of the firm: managerial behaviour, agency costsand the ownership structure, Journal of Financial Economics, 3(4), 305-360.

Li, K., Niskanen, J. \& Niskanen, M. (2019). Capital structure and firm performance in European SMEs: Does credit risk make a difference?, Managerial Finance, 45(5), 582-601.

Margaritis, D., \& Psillaki, M. (2007). Capital structure and firm efficiency. Journal of Business Finance \& Accounting, 34(9 - 10), 1447-1469.

Matar, A. \& Eneizan, B. (2018). Determinants of Financial Performance in the Industrial Firms: Evidence from Jordan. Asian Journal of Agricultural Extension, Economics \& Sociology, 22(1), 1-10

Modigliani F. \& Miller M. (1958), The cost of capital, corporation finance and the theory of investment. American Economic Review, 48, 261-297.

Muzir, E. (2011). Triangle Relationship among Firm Size, Capital Structure Choice and Financial Performance. Journal of Management Research, 11(2), 87-98.

Naseem, M. A., Lin, J., Rehman, R., Ahmad, M., \& Ali, R. (2020). Does capital structure mediate the link between CEO characteristics and firm performance?, Management Decision, 58(1), 164-181. 
Nawaz, A., Ali, R., \& Naseem, M. A. (2011). Relationship between capital structure and firms performance: a case of Textile sector in Pakistan. Global Business and Management Research, 3(3/4), 270-275.

Nguyen, P. V., \& Hosseini, J. C. (2019). The impact of product diversification and capital structure on firm performance: evidence from Vietnamese manufacturing enterprises. Journal for Global Business Advancement, 12(1), 95-116.

Nguyen, T. X. H., Pham, T. H., Dao, T. N., Nguyen, T. N., \& Tran, T. K. N. (2020). The Impact of Foreign Ownership and Management On Firm Performance in Vietnam. The Journal of Asian Finance, Economics, And Business, 7(9), 409-418.

Önel, Y. C., \& Gansuwan, P. (2012). The Influence of Capital Structure on Firm Performance: A quantitative study of Swedish listed firms. The Journal of Risk Finance, 12(3), 226-241.

Rahaman, M. A., \& Alam, M. N. (2014). Influence of capital structure on firm performance: Evidence from Bangladesh. International Journal of Business and Management, 9(5), 184-193.

Ramadan, Z. S., \& Ramadan, I. Z. (2015). Capital structure and firm's performance of Jordanian manufacturing sector. International Journal of Economics and Finance, 7(6), 279-284.

Rouf, D. (2015). Capital structure and firm performance of listed non-financial companies in Bangladesh. The International Journal of Applied Economics and Finance, 9(1), 25-32.

Sadeghian, N. S., Latifi, M. M., Soroush, S., \& Aghabagher, Z. T. (2012). Debt policy and corporate performance: empirical evidence from Tehran Stock Exchange companies. International Journal of Economics and Finance, 4(11), 217-224.

Saeedi, A., \& Mahmoodi, I. (2011). Capital structure and firm performance: Evidence from Iranian companies. International Research Journal of Finance and Economics, 70(11), 20-29.

Shamsuddin, Z., Ismail, A. G., Yusoff, W. S., Mahmood, S., \& Daud, W. M. N. W. (2018). Capital Structure, Investment, Members Return, And Performance: Some Malaysian Cooperative Evidence, National Academy of Managerial Staff of Culture and Arts Herald, (1), 927-931.

Spitsin, V., Vukovic, D., Anokhin, S., \& Spitsina, L. (2020). Company performance and optimal capital structure: Evidence of transition economy (Russia), Journal of Economic Studies, 48(2), 313-332.

Tailab, M. (2014). Analyzing factors effecting profitability of non-financial US firms. Research Journal of Finance and Accounting, 5(22),26-38.

Tayem, G. (2018). The Determinants of Debt Maturity: The Case of Jordan. Academy of Accounting and Financial Studies Journal, 22(1), 1-13.

Tristan, N. \& Huy-Cuong N. (2015). Capital structure and firms' performance: evidence from Vietnam's Stock Exchange, International Journal of Economics and Finance, 7(12), 1-10.

Vo, D. H., \& Nguyen, T. M. (2014). The impact of corporate governance on firm performance: Empirical study in Vietnam. International Journal of Economics and Finance, 6(6), 1-13.

Wassie, F. A. (2020). Impacts of capital structure: profitability of construction companies in Ethiopia, Journal of Financial Management of Property and Construction, 25(3), 371-386. 